\title{
MUKAVELELERIN TASNIFI
}

\section{VE B. K. DIŞINDA BIRAKILMIS OLAN MUKAVELELER VE BILHASSA SULH MUKAVELESI}

\section{Vasfi Raşid Sevig}

I - A - Mevzuu eşyaya taallûk eden yani esya ile ilgili bulunan akitler en eski akitlerdir.

1. -- Eşyanın tamamiyle devir ve naklini amaç edinen rüknü eșyanın devir ve nakli olan, yani eski tabirimiz ile hükmü mülkiyet olan akitler ya ıvaz karşılığında yapılır veya ıvasız olur.

a) Ivazsız olur ise bağışlama adını alır. Bağışlamanın hükmü müikiyettir; rüknü temlikin ıvazsız olması ve hayatta olan kimseler arasında yapılmasıdır. Çünkü ıvazsız temlik ölüme bağllolarak yapılır ise bağışlama olmaktan çlkar ve vasiyet olur: "hibe hayatta olan kimseler arasında bir tasarrufdur ki anınla bir kimse, karşlığında bir lvaz taahhüt edilmeksizin malının tamaminı veya bir kısmını diğer bir kimseye tem'jk eder." (B. K. 234 f. 1.). Ivazsız tasarruflar bağıslama ve vasiyete şamil olmak üzere teberrü adını alır.

b) Temlik ıvaz karșllı̆ında yapılır ise ıvazın mal vey para olmasına göre trampa (B. K. 232) veya satım (beyi) olur (B. K. 184). Beyiin hükmü mülkiyettir: Satıcının semene alıcinın da satılana malik olmasıdır; rüknü satılan ile semendir: Satım bir akittir ki onunla satıcı satılan mall müşterinin borçlandığı semen karşılığında müșteriye teslim ve mülkiyeti ona nakil eylemek borcunu yüklenir" (B. K. 182).

Eğer bir tarafın vereceği ıvaz temliki yapan tarafın borcundan kurtulması teskil ediyor ise tediye makamına (yerine) gecri ek üzere vermek olur (B. K. 170; 311). Borçlunun, borcunu para ile ödemekten ise hir mal vererek ödemesi ıvazsız bir temlik değildir; temlikin karşlığg, ıvazı borçlunun borcundan kurtulmasıdır.

Eğer temlikin karșllğı temliki yapamın ortaklık kazancindan faideJenmesi ise o zaman temlik sermaye veya ortaklık hissesi adın alır ve alım satım hükümlerine bağlı olur (B. K. 521) (T. K. 125 No. 3 ; 131, 
132). Temlik edilecek eşanın ayin veya para olmasına göre de temlik ya alım satım veya ödünç olur isede ödünç hakikatte paranın kullamılznasının devridir. Yalnız para istihlâk edilmeden kullanılamıyacağından mülkiyetin devri lâzım gelmektedir.

2. - Eğer konusu eşyanın yalnız geçici olarak kullanılmasının terki ise kullanılmanın terki de ya ıvazsız veya ivazlı olur.

a) Kullanma ivazsiz olarak terk edilmis ise bagit egreti verme akdi olur. Bağışlama eşyanın mülkiyetinin bedava bağıslanması ise ikreti de "bir akittirki onunla igreti veren bir şeyin bedava kullamılmasın igreti alana birakmak ve alan dahi o şeyi kullandıktan sonra geri vermekle ödevli olur." (B. K. 299).

b) Eşyanın kullanılması ıvaz karşılığında oluyor ise vakılır; ıvaz mukabilinde kullanılacak şey bir ayin ise bağıt kira akdi olur; kutianılacak şey para ise bağıt ödünç akdi olur.

Gerek kira akdinde gerekse ödünç akdind’e ıvaz daima paradır ki birincisinde kira bedeli ikincisinde faiz adlarını alır; binaenaleyh her iki bagit karşlık olarak verilecek ıvazm mahiyetiyle de birbirinden ayrilir. Her iki bağıt da alım satıma karşılık teşkil eden akittir. Alım satımda esyanın mülkiyeti satılıyor kira ve ödünç de ise esyanın yalmı menfaati satılıyor. Eşyanın kullanılmasının başka bir esyanın kullanılması kar\$1lığında satılması yani trampaya benzeyecek ve tekabül edecek bir sekil de yapilmasi dahi hem tasavvur edilebilir hem de caizdir.

"Adi kira bir akittirki kiralayan, onunla kiraciya ücret mukabilinde hir şeyin kullanılmasını terk etmeği borçlenır." (B. K. 248).

ödünç bir akittir ki; onunla ödünç veren, bir miktar paranın mülkiyetini ódünç alan kimseye vermekle; ödünç alan kimse dahi miktar ve vasıfta aynı olan parayı geri vermekle mükellef olur. (B. K. 306).

3. - Eğer aktin konusu esyanın sadece ivazh veya ıvazsız olarak saiklanılması ise ıvazsız olduğu takdirde bagit vedia olur ki halk dilinde buna emanet denir.

"İda bir akittir ki onunla kendisine ida edilen kimse (müstevdi) ida eden (mudi) tarafından verilen seyi kabul ve o şeyi emin bir yerde sallamağı üstüne alır. Müstevdi prensip itibariyle ücret istemez (B. K. 463).

Ivazlı olduğu takdirde ardiye mukavelesi (B. K. 473) veya hancllara otelcilere ve ahır sahiplerine eşya bırakma (tevdi) mukavelesi adını alırlar (B. K. 478).

B. - Konuları hak olan bagitlar.

Konuları mülkiyet hakkından gayri bir hak olan akitlerde konuları eșya yani mülkiyet hakkı olan akitler gibi tasnif ve taksim olunur. 
1. -- Temlik edilen haklar, meselâ alacak hakkı bağıșlanabilir (B. K. 169 F. 2) ; satilabilir (B. K. 169) ; trampa edilebilir; şirkete sermaye olarak konabilir (T. K. 129) ; tediye yerine geçmek üzere verilebilir (170).

2. - Hak rehine konabilir.

3. - Hakdan kismen veya tamamen, ivazh veya ivazsiz olarak feragat edilebilir. itbra, sulh vesaire gibi.

C. -- Konusu hizmet olan akitler.

a) Hizmetin ıvazsız olarak yapılması pek nadirdir. Hizmetin bağıslanmas! ancak dostlar arasında gözükebilir, çünkü insan çalışması iie yani işłemesi ile yaşar. Bununla beraber vekâlet esas itibariyle ıvazșiz ijir hizmettir. Masrafların istemeğe hakkı olan vekil, şart edilmiș olmadikç̧a ücret isteyemez: "Vekâlet bir akittir ki onunla vekil sözleşme ile yapmasını üsẗ̈ne aldı̆̆ hizmeti yapmağı borçlanır, vekilin ücret alması sözlesilmiş ise veya âdet ise ancak o zaman vekil ücrete hak kazanir" (B. K. 386).

$\mathrm{Bu}$ arzedilen tasnif ve taksim tamam olmadığı gibi itirazdan da masun kalnayabilir. Fakat yine de bu arzedilen temel üzerine kurulacak bir tasnif tamamlanmağa en elverişli bir tasnif olur; çünkü her mukaveleye vücut verebilecek olan bütün elemanlar (unsur) bilinmekte olduğundan bu unsurların birbirleriyle karıștırılmasından çıabilecek mukavele. lerin hepsinin bu tasnife sokulması mümkün olur. .

II - Borçlar kanunumuz akit nevilerini aşağı yukarı yukarda arzeylediğimiz tasnif esası dahilinde tasnif eyler ve dört büyük guruba ayır:r:

1. - Esyanın devir ve temlikini sağlayan akitlerdir ki menkul ve gayri menkul alım satımından; trampadan, bağışlamadan ibarettir. (A1tincı bap Madde 182 - 247).

2. - İkinci gurup eşyanın kullanılmasının terkini temin eden akitlerdir ki adi kira, hasılât kirası, eğreti ve ödünç mukavelelerinden ib:ırettir (yedinci ve sekizinci baplar madde 248 - 312).

3. - Üçïncï gurup eşyanın muhafazasını sağlayan akitlerdir ki vödia adı altında toplanmıs bulunan ıda, ardiye ve otelcilerle ahır sahipierine esya tevdii mukavelelerinden ibarettir (Ondokuzuncu bap madde $463-482)$.

4. - Dördüncii gurup konusu hizmet olan akitleri toplar ki hizmet, istisna ve neşir akitleri ile vekâlet ve vekâlete benzeyen bağıtlardan (itibar mektubu ve emri; dellallık) ve komisyon akdinden ibarettir.

5. - Borçlar kanunumuz bu guruplar dişnda bir gurup da garanti bagitlarına ayırır; kefâlet (yirminci bap madde 483 - 503) ve şartı cezai (madde 158) gibi. 
6. - Kazanılması veya gayip edilmesi şüpheli olan kumar ve bahse ait mukavele ile irat mukavelesi (kayd hayat lie irat ve öliinceye kader bakma madde 507 - 519) birer müstakil gurup halinde yirmi birinci ve yirmi alimeı bapların konusunu teşkil eylemektedir.

7. -. Adi sirket bütün ortaklik esasının temeli ve borçlar kanununun yirmi üçüncü babının (madde 520 - 541) konusunu teşkil eder.

III. - Akitlerin sistematik bir tasnifini yapabilmek oldukça güçtür; fakat bazı mükellefler akitlerin nev'ini teşkil ettikleri hukukî münasełetlerde yalnız bir tarafı veya her iki tarafı tamam yahut eksik bir tarzda borclandirilmasina göre de bir tasnife tabi tutuyorlar.

1 - a) Yalnız bir tarafỉ borçlandıran hukukî muameleler:

İlân yolu ile bedel vadi (B. K. M. 8); senetler)

Kıymetli evrak (kâğıt) çıkartmak (ticarî senetler, hamiline yazılı

b) Yalnız bir tarafi borçlandıran akitler:

ödünç; devlet ödüncü (istikraz); bağıșlama; kumar ve bahis.

2. - İki taraf 1 eksik olarak borçlandıran bağıtlar:

Ariyet (madde 301). Esyayı muhafaza mukaveleleri ki ya basska bir mukavelenin fer'i olur (meselâ alım satımın; komisyon mukavelesinir B. K. 418) ; yahut özel bir bagıt, yani bagitın esaslı muhtevası yahut münhasiran konusu olur ki (B. K. 464) vedia, ardiye, otelcilere esya tevdii mukaveleleri. - Rehin - Vekâlet - Havale.

3. - Iki tarafı tamam olarak borçlandıran bağıtlar:

Alım satım ve muhtelif nevileri. - Trampa. - Adi kira ve hasılât kirası. - Hizmet akdi. - Çiraklık mukavelesi. - İstisna, akdi. - Neşir akdi. Deliallık (simsarlık). - Komisyon. - İrsal komisyoncusu. - Nakliye mukaveleleri. -

IV - a) Sözleşmelerin mahdut olup olmadığı meselesi tartışmalıdrr. En ziyade kabul edilen fikre göre aynı haklar mahdut olduğú halde - çünkü amme intizamina taalluk eder ve bu sebepten taraflar yeni bir ayni hak ihdas edemezler - akitler gayri mahduttur ve taraflar iradele. riyle yeni yeni akitier ihdas edebilirler. Plâniol bu kanaatin Roma hukukunun hafızalarda bıraktığı izlerden doğmakta olduğunu ileri sürmek. tedir. Çünkü Romalılar adlandırılmamış (borçlar hukukuna girmiş bütün akitlerin birer adları vardır) mukaveleler de kabul ederlerdi. Tesmiyesiz mukavelelerin, yani kendilerine birer isim verilmemiş mukavelelerin vücudunu kabul etmek fertlere, evvelce kabul edilmiş çerçeveler içine giremiyecek yeni mukaveleler ihdas edebilmek imkân ve yetkisini kabui etmekle ayni sey olur. Modern hukukun Roma hukukundan daha dar 
olamıyacağı; modern hukukun Roma hukukundan daha az müsamahalı ve daha az geniş bulunamlyacağı düşüncesi modern hukukta da tesmiyesiz mukavele erin görülebileceği kanaatini doğurdu. Halbuki Romalılarır mukavele kalıbı olarak kabul eyledikleri stipulatio (ki eski hukukumuz buna sıga derdi) dışinda yapılabilecek bagıt sayısı pek azdı. Binaenaleyh Rornada yapllan şey sıga ile (resmi sözlerle) yapllmiyan bagıt sayısmi arttırmaktan ibaretti. Sıga kisvesine (elbisesine) bürünmemiş bir mukavele tarafları borçlandırmadığından tarafların bir esyanın teslimi ile de borçlandırabileceklerinin kabulü suretile bahis mevzuu arttırma ve çoğaltma vücuda getirilmeğe başlandı.

Esyaya Romallar Res veya Re derler. Re mukaveleler yani eski hu. kukumuzun tabiriyle kabz ile (pençeye, avuca almakla) vücuda gelen mukaveleler ödünç, emanet, egreti vedia, rehin idi. Fakat artık ne fikih ne de modern hukuk bagitlarda lâfza (sigaya) ve mebnaya (yapıya yani sekle) itibar etmeyip manaya (ruha) ve maksada itibar eder olduğundan buituin bagitlar tarafların sadece rızalarına dayanır ki bu hali frenkler (hislerin, rızaların "sensus" birbirine uygun o'duğunu "cum" ifade eden tabir ile) consensuel mukaveleler adını verirler. Türk borçlar hukukunda asla bir Re mukavele mevcut değildir; bütün mukaveleler ödünড̧ de dahil olmak üzere birinci madde hükmünce consensuel'dir. Binaenaleyì Plan:ol'un kanaati dahilinde ifade etmek lâzım gelirse denebilir ki Ro. malılarm sıga usulü dışında bagıt yaplabilmesi için kabul eyledikleri kolayìkları modern hukukun kabul etmesine asla lüzum yoktur. Roma hukukçuları adlandırılmamış mukaveleleri ihdas ederlerken yeni bir mukavele ihdas etmiş olmuyorlardı; çünkü adlandırılmamış mukavele'eri hepsi sıga ile yapılabiliyordu; binaenaleyh Roma hukukçuları adlandırımamıs mukaveleleri ihdas ederlerken borçlanma usulünü geniş:etmiş vo yumuşatmıș oluyorlardı; yalnız lâfza (mukavele esnasında söynlenmiş sözlere ve yalnız söylenmiş olan sözlere) itibar eden sıga usulünden gayri bir usul ile de borçlanılabileceğini kabul ettirmiş oluyorlardı; yoksa yeni mukavele tipi ihdas etmiş olmuyorlardl. Modern hukukun Consensuel usulï yani borcu rızaların uygun düşmesinden çlkartan ve doğurtan usulü adlandırılmamış mukavele sistemine asla lüzum göstermiyor. Bu itibarla modern hukukta adlandırılmamış mukavele yoktur.

b) Adlandırılmamıș mukavelelerin varlığını kabul ettiren ve yaniıșllkıаra vücut veren diğer bir sebep de mürekkep mukavelelerin vücududur. Mürekkep mukaveleler borçlar kanununda adı konmuş ve tasnife tabi tutulmus bir kaç mukaveleyi tek bir mukavelede toplayan bagitlardır. Bunun en güzel misalini otelcilere tevdiat mukavelesinde görebiliriz (B. K. 478). Otelcilere tevdiat mukavelesi diğer mukavele’erden ayrı ve 
basit bir mukavele değildir; mukaveleler topluluğudur yani gurubudur: Evvelâ bir ayin kirasıdır (odanın kiralanması); sonra hizmet aktidir (otel muistahdemlerinin yapacakları hizmet); yiyeceğe ve ısınacağa ve saireye ait mal itası taahhüdï (Ticaret K. madde 20 No. 1); ve nihayet yolcu esyalarının idaı mukavelesi.

Bir tiyatro direktörü ile halk arasında vaki mukavele dahi hemen hemen ayni mahiyettedir. Tiyatro direktörünün halk ile yaptığı mulsavele evvelâ bir yer kirasıdır; sonra bir sey yapmak taahhüdüdür (temsili vermektir) ki istisnaa girer. Acaba tiyatroda gardroba esya tevdii hususunda otelcilere tevdiata klyas edilerek tiyatro direktörünün mesiliyetini intaç eyler mi? Başka bir tabir ile borçlar kanununun 478 inci maddesinin genişletilmeğe müsaade ve imkânı var mıdır? Her halde düşünülecek bir noktadır.

c) Netice olarak Planiol yeni bir mukaveie ihdas edilemiyeceği, yapllabilecek tek şeyin belirli olan çeşitli unsurlarn bir araya getirmekterı ibaret yani mukaveleler kombinazonu vücuda getirmekten ibaret olduğ kanaatine varıyor. Binaenaleyh bu kanaate göre tesmiyesiz mukavelelerin bir adl da mürekkep mukavelelerdir. Kanunun sarahaten bahis ve tanzim etmediği bu mukaveleler borçlar kanununun umumî hükümlerine tabi olur.

V. - Borçlar hukukunun dişında yer almış olan muhtelif bagitlar. Borçlar hukukunun umumî hükümleri ihtiva eden birinci kısminm her hangi bir mukaveleye tatbik edileceği medeni kanunun 5 inci mad่desinden zahir olmaktadır. Bununla beraber bu hükümler mevcut ie mutasavver bütün halleri tanzime kâfi gelmez. Bu sebepten borçlar kenunu ikinci kısmında yukarıda tasnifini yaptığımız en mühim bagitların her biri için özel hükümler de koymuştur. Borçlar hukukunun ikinci kıșmini "on sekiz münferit kanundan ibarettir" şeklinde ifade edenler de vardır. Gerçektir ki ikinci kısımda mevcut on sekiz mukavelenin her bir: ayrı bir kanunun mevzuu kılınabilir. Meselâ alım satım beş fasılda tanzim edilmiș başlı başına bir knundur; vekâlet ụ̈ fşlda tanzim edilmiş müstakil bir kanundur. Bu müstakil kanunun umumî hükümleri komisyon gibi diğer müstakil bir kanuna da tatbik edilebilir. Bu müstakil kanunların özel hükümleri o mukaveleler hakkında umumî hükümlere üstün tutuluyor.

Borçlar kanununun dişında kalmıs böyle müstakil kanun hükmünde başkaca bagitlar mevcut mudur? Barçlar kanununa girmeyip de başka kanunlar arasına katılmıs mukaveleler şunlardır: 
a) Medeni kanunda mevcut mukaveleler:

1. - Evlenme mukaveleleri; 2 - Miras mukavelesi (M. K. madét 492 - 496) ; .3 - Taksim mukaveiesi (M. K. madde 611 - 613). Taksin mukavelesi hükümleri her hangi müsterek bir maln taksiminde tatbik edilebilir; 4 - Menkul rehni (M. K. 853 - 882).

b) Hukuk yargilama usulü kanununda mevcut mukaveleler:

1. - Katî yemin (madde 344 - 354) katî yemin - ki dâvacilaróain birinin diğerine yemin teklif eylemesinden ibarettir - bir mukaveledir. Bu mukavele mucibince teklif edilen yemin diğeri tarafından eda edilince iddiasmn isbat eylemiş olur: "Yemin teklif olunan kimse yemini edaya hazır oiduğunu beyan ettikten sonra diğer taraf teklifinden sarfınazar ile başka delil ikame edemez" (Madde 350).

Binaenaleyh katî yeminin neticesi hasımların uzlaşmalarına (dâvadan sulha) benzetilebilir; çünkü husumete yani dâvaya son verir. Bununla beraber katî yemin sulh değildir. Çünkü sulh iki tarẫ̂tan karşs. lıklı fedakârlık ister: "Sulh müzakeresi esnasında geçen ikrar muteber değildir" (Nadde 236 fıkra 3).

Katî yemin eda eden kimse dâvayı kazanır; yeminden imtina edẹ kimse dâvayı gaybeder: "Kendisine yemin teklif ounan lkimse yemin etmez veya yemini hasma reddeylemezse yeminin mevzuun teșkil eimis olan meseleyi ikrar etmis sayilur. Kendisine yemin reddownan kimsemn yeminden imtana dahi ikrar sayllı" (Madde 347).

2. - Tahkim: Tahkim hususi bir mukavele (tahkimname) ile yapllabileceği gibi her hangi bir mukaveleye bir şart koymak (tahkim şaìt1) suretiyle de vücuda getirilebilir -(madde 516 - 518). Nizann hailini hakeme tevdi mukavelesi önemli bir mukave'edir; aralarmda husumet bulunan iki kimsenin, nizalarının hallini üçüncü bir şahsın takdirine terì eylemek hususunda anlaşmalarıdır. "İki taraf aralarındaki nizaı hal için hakem tayin edebilirler" (madde 516). Nizann halli için seçimniş üçüncü şahsa hakem deniyor. Demek ki tahkim taraflar arasında bu husus için yapulan mukavelenin hakem tarafindan icrasıdır. Hakemin kararı kaz:yei muhkeme (madde 237) kuvvetindedir (madde 533). Mahkeme ka!cmine tevdi ediimekle icra edilmek kabiliyetini alir (madde 532). Hakem. mukavelesi nizam halli için mahkemenin yerine bir hakem koymak ve geçirmek olmasından ötürü yerini usul kanununda bulmuştur.

Meveut bir nizan tahkim yolu ile hal edilebileceğinde hic süphe yoktur. Fakat doğacak ihtilâfların hakem vasitasiyle hal edileceğine dai. konmuş bir şartın (tahkim şartmmn) muteber olvp olrwigacağ! hakkinda tarțşinalar olmuștur; ihtilâf mevzuunun ve hakemlerin şahıslarmın 
meçhul bulunması şartın batıl olduğunu iddia ettirmiştir. Fakat usui kanunumuzun 516 nci maddesi: "Tahkim, her hangi bir mukaveleye bundan çlkması muhtemel nizain hakemler vasitasiyle halline dair bir sart da koymak" suretiyle de yaplabileceğini tasrih etmekle butlan iddia eden. kanaatları red eylemiş oluyor.

3. - Sulh: Köy kânununun uzlaştırma diye ifacle eylediği (Köy $\mathrm{K}$. 50) sulh münazaalı bir hak üzerinde hak sahibinin bir fedakârìk kabu ${ }^{3}$ etmesi ve dâvalının sulh bedeli adını taşıan bir ivaz vermesi şartını havi bir uzlaşniadır. Bu uzlaşma dâva esnasında yapılmakta olmasından bořslar kanununa girmemiştir. Fakat usul kanunu sulhü yalnız 63 ve 236 ncı maddeierinde sadece ağza alıyor. İcra ve iflâs kanunu da 38 inci maddesinde "mahkeme huzurunda yapllan sulhların ilâm hükmünde" olduğunu zikr ile iktifa ediyor ve hiç bir kanunda sulh mukavelesi hakhinda bir kaide konmuş bulunmuyor. Demek ki sulh mukavelesi hakkinda özei bir hüküm kabul edilmiş olmayıp tamaniyle umumî hükümlere tâbì bırakılmış oluyor. Bu itibarla sulh, inıkatında B. K. Mad. 1; şeklinde mad. 11, tabi kalyyor. Sulha âriz olan veya sulha tesir eden hata ve fesatiar hakkında denebilirki; ahlâka aykırı olması B. K. 20 inci maddesi gabın bulunması 21 inci maddesi; esasl hatalar 23, 24 maddesi, ikrah 29, 30 maddesi hile 28 inci maddesi hükümlerine tabi kalır.

A. - Mecelie sulhü: "Nizaı rıza ile kaldıran bir bagıt'dır" diye tarîิ eder (madde 531). Husumete vekâlet yani dâvaya vekâlet sulha vekàleti müsteizim olmıyacağ hususu hem mecellede (madde 1542) hem de usul kanunumuzda (madde 63) zikir edilmiştir. Binaenalıyh dâvaya vekil olan avukat veya dâva vekilinin dâva sahibinden (müekkilinden) izìi almadan o dâvadan sulh olsa sahih olmaz. Medeni kanunun 405 inci maddesi No. 8 mucibince vâsi de, sulh mahkemesinden izin almadıkça sulh aktinde bulunamaz.

B. - Modern hukukta sulh çözülmesi lâzım çifte bir mesəle arzeyler. $\mathrm{Bu}$ meselelerden birincisi hukukta sulha verilecek yeri tayin etmektir. Fransı, İtalyan, İspanyol ve Alman kanunları-sulha, borc münasebetleri arasında bir yer ayırmaktadir. Portekiz kanunu sulhun intaç eyleyeceği aynî neticelere ve mukaddem yapılmış hukukî muamelelere nâzaran ona - dilimizde "uzun kira" adiyle adlandırılmış olan çok uzun ve hatta daimî müddetle yapılan - hasılât icarı ile tescil arasında bir yer vermistir. Avusturya kanunu sulhu hak ve borçların sukutu veya tadiii gibi telâkki eylediğinden ona borçlar kanununun umumî kısmında yer vermiştir ki bu da sulhun mahiyetinin en güzel bir telâkkisi olsa gerektir. 
İkinci mesele sulha ait bahis ve hükümleri kanundan büsbütün clkartmaktır ki İsviçre ve Türk kanunları bu çözüm tarzını kabul etmişlerdir. Netekim usule ait prensiplerin cari ve hakim olduğu tahkim ile kałi yemin medeni kanunun ve borçlar kanununun dişinda burakılmıștır. Suin de, tahkim gibi katî yemin gibi borçlar hukuku dışnda hususî bir tanzime muhtaçtır.

Alman medeni kanunu sulha borçlar hukukunun tek bir maddesini tahsis ey:emistir 779 rakkamını taşıan bu madde de hem sulku tarif eylemiştir hem de sulhun hukukî veya fiilî hata ile batıl olacağin tayin etmiştir.

1. - Sulhun, Alman kanununa göre tarifi: Sulhun Aiman kanunuidakı tarifini anlayabilmek için evvelâ onun mahiyetini tayin etmek hnsusundaki düşüncelere nüfuz eylemek lâzımdir. a) Sulh ekseriya, mürazaalı olan hakkı kısmen olsun kabule vardığından deyin ikrarna benzetilir; b) Sulhde esaslı fikir taraflar arasinda, münazaalı olan veya taraflarca sübjektif bir tarzda şïpheli bulunan bir hukuki münssebeti karşlıkin fedakârliklarla tesbit eylemek midir? c) Yoksa sadece bir nizaa son vermek midir? d) Yoksa sulh bir hukukî münasebete dair taraflarca mevcut sübjektif bir şüpheyi, tarafların birbirlerine karș! ileri sürduh. leri iddialarından geri çekilmek ve birbirlerine karşı terklerde ve tavizlerde bulunmak suretiyle ortadan kaldırmak midır? e) Suha varmak için kabul edilen fedakârlıklar netice itibariyle nizalı olan hulkukî münasebçi tesbit edeceği yerde ya ortadan kaldırmağa veya değistirmeğe varıor; binaenaleyh sulhun hakikî amacı nizal veya şahsî veya aynî o'abilecek olan hakka ait şüpheyi ortadan kaldırmak oluyor.

Alman kanunu bu çeşitli mülâhazalar arasında vaziyet almakta ve sulhu şu tarzda tarif eylemektedir:

"Su'h taraflar arasında vaki bir nizal veya bir hukukî münasebete ait şüphneyi yahut bir iddianın gerçekleştirilebileceğinde vaki omniyetsiz. liği karşılıklı fedakârlıklarla (1) hal eden mukaveledir."

Misal: A ve $B$ den her biri muayyen bir ata kendisinin sahip olduğunu iddia eylemektedir. Bunlar şu suretle aralarında sulh akit edebilir. $\mathrm{B}$ atın A ya ait olduğunu kabul edecektir; A da buna mukabil B ye 100 . lira verecektir. Alman kanunu medenisinin sulhu tarifi, üç parçadan mü-

(1) Fransız medeni K. (madde 2044) sulhu "taraflarm, doğmuș bir nizạa scn vermek veya doğacak bir nizaı önlemek için yaptıkları mukaveledir" şeklinde taiłf eder. Bu tarif eksiktir; çünkü sulhu feragat ve kabulden ayıracak farikayı ihtiva etmiyor. Tarafların nizaın bertaraf kılınmasını elde etmek için yaptıkları karşılıklı fedakârlığı nazara almıyor (Planiol ve Ripert cilt XI. No. 1563). 
rekkeptir; birinci parça sulhun nizaı hal eden mukavele olduğunu gösterir. İkinci parça her hangi hukuki münasebet üzerinden tarafların şüphesini kaldıran bir mukavele olduğunu bildirir. Binaenaleyh, çocuğun nesebinin sıhhati gibi üzerinde taraflarin tasarruf edemedikleri hukukí münasebetler müstesna olmak üzere bütün hukukî münasebetler sulhun konusu olabilir; imdi aile hukukuna, miras hukukuna, aynı hakka ve borçlar hukukùna ait bütün hukukî münasebetler tarafların bu münasebetlerde tasarruf edebilmeleri şartiyle sulhun konusu olabilir. Meselâ bir evlenmenin mevcut olup olmadığı hakkında bir sulh yaplamaz; çünkü taraflarm bunda tasarruflara yetkileri yoktur. İmdi yalnız medeni hukuka ve borçlar hukukuna giren hukukî münasebetler sulhun konusu olmakla kalmaz meselâ ilâm gibi yani ilâmın tavzihi, ve icrası gibi diğer hukuka ait hâdiseler gibi (Usul madde 222 - 225) hukukî münasebețer dahi sulhun konusu olabilir (1). Demek kesinleşmiş bir ilâm kaziyei muhkeme teşkil etmek ve tarafların hukukî münasebetleri hakkında hiç bir şüpheye mahal vermemek itibariyle sulh mevzuu olamaz ise de tavzihi yani hudut ve şümulïnün tayini hususları sulh konusu kılınabilir.

Niza veya hukukî münasebet üzerindeki şüphe, hukukî münasebetin varlığı veya yokluğu üzerinde yahut bu hukukî münasebetten doğacaił iddianın şümul ve muhtevası hakkında hülâsa hukukî olabileceği gibi fiilî de olabilir; meselâ, borçlunun malı vaziyetinin çok kötü olması dolayısiyle iddianın ne derecelerde gerçekleştirilebileceğine ait de, yani fiiîi de olabilir. Şüphenin sübjektif olması kâfidir, asla objektif olmasına lïzum yoktur. Bu itibarla taraflar kaziyei muhkeme teşkil etmiş olan münasebetleri hakkında dahi sulh aktedebilirler; elverir ki taraflarca kesinleşmiş ilâmın mana ve medlûlü yahut icra kabiliyeti sübjektif tarzdá şüpheli bulunsun.

3. - Ưçünë parça nizain veya şüphenin karşlıklı fedakârlıklar la hallidir. Eğer dâvalı dâvacının bütün iddiasını, ondan karşıllı bir ıvaz almadan kabul eder ise ortada sulh olmaz sadece kabul bulunur (hukuk M. usulü K. madde 92). Yahut dâvacı, dâvalıdan karşılık bir ıvaz aỉmadan dâvasindan vaz geçer ise yine ortada bir sulh bulunmaz sadece feragat bulunur (Hukuk M. Usulü K. madde 91). Hülâsa sulh iki taraftan karşlıkk fedakârlık ister; aksi takdirde sulhdan ayri veya başka bir mukavele vücuda gelir. Karşlıklı fedakârlığın kıymetçe eşit olması asìa lâzım değildir. Karşılıklı fedakârlıklar arasında büyük nisbetsizlik buiı̀-

(1) "Hakkı kesinleşmiş bir hükme istinat eden kimse ilâmın icrasının maruz kaldığı fiilî güçlükler karşısında mahkûmun aleyhi ile sulh olması caizdir" D. 1902. I. 566 . 
nabilir bu sebepten daima karşllklı taahhüdü ihtiva eden bir mukaveie olan sulhun daima da mutlâka malûm manada ivazlı bir mukavele olduğ i iddia edilemez. Meselâ A nın muacceliyet kesbeden alacağını iki üç gün tecil etmesi için veya icra merciinde yahut mahkemede açtığı takibi sadece geri alması için B yüzlerce liralık bir fedakârlı̆̆ kabul edebilir. Bı misalde A nın kabul ettiği fedakârlık para ile ölçülebilen bir fedakârlı̈ değildir. (Cosack U. Mitteis Bürger. Rochts). İsviçre hukukunun sulhu telâkki tarzını anlamak için Emile Thilo'nun federal mahkemenin sulha dair verdiği kararlar hakkında yazılmış makalesi gayet güzel bir rehberdir. (j. d. T. 1932 sah. 450 - 455).

Rossel sulhu, eserinin III üncü cilt Sah. 222 de "bir nizar bitirmeğe veya doğacak bir nizal önlemeğe yarayan ve a) taraflarm rızasiyle vücut bulan, b) Tarafları karşllklı borçlandıran, c) Ivazlı bir mukaveledir. Hakların münazaal olması veya sadece münazaa edilebilmeğe müstait ve müsait bulunması; şüphenin bir hakkın mevcudiyetine, doğumuna yahut şimulüne ait bulunması hususları müsavidir. Von Thur ise eserinin ( 37 hata) bahsinde (Arsebük $\S 41$ hata sah. 428) diyor ki: "Her sulhta hens a) karşllıklı fedakârlıklar yapılmak suretiyle giderilmek istenilen ihtiiâflı (binaenaleyh șüpheli) noktalar ve hem de b) iki tarafın varlığını kabul eyledikleri ve mukavele ettikleri sulh akidinin sartı kıldıkları vakılar göze çarpar. Meselâ (A) nın lehtari olduğu bir vasiyetin miktarı hakkında A ile B arasında çımış bir ihtilâfa son veren sulh akdinde bunların rızalarındaki uygunluk, vasiyetin sıhhatinde ittifak eylemiş olduklarını kabul ettirir. Eğer her ikisi de vasiyetin batıl olduğunu bilseler idi B 'A' ya bir edada bulunmağı taahhüt etmezdi ve (A) da B den hüsnüniyetle bir șey isteyemezdi. (A vasiyetin batıl olduğunu bile bile kendisine bir edada bulundurtur ise hile yapmis olur) "Her iki tarafın vasiyetin sahih ve muteber olduğu fikir ve kanaatinde olması bu fikir ve kanaatin her iki taraf için ayni önemi taşıması sulh akdinin esasıdır.,, Binaenaleyh Von Thur bu misal ile sulhun shhhati için hatanın mukavelenin esaslı temelini teşkil eden olaylara aid olmaması lâzım geleceğini göstermiş oluyor.

Federal mahkemenin amme hukuku dairesinin yayınlanmamıs bulunan 29 Nisan 1932 tarihli kararında (taraflar: Cottier-Jenevre büyük şurası) sulh şu tarzda tarif edilmiştir. "Sulh bir akiddir ki anınla taraflar karşlıklı fedakârlıklar kabul etmek suretiyle belirli olmayan bir hukukî münasebeti belirli bir münasebette tahvil ederler" Ayni karar tarafların yalnı dava esnasında sulh olmayıp davadan evvel de sulh olabileceklerini, çünkü bir ihtilâfı önlemenin de münasip olacağını zikreder. 
Romadanberi bir mukavele olarak kabul edilen sulh mukavele hükümlerine tâbidir.

1. - Mukavele evvelâ şahislarda ehliyeti icabettirir, binaenaleyh sulh taallûk eylediği eşyada tasarrufa yetkili olan taraflar arasında bahis konusu olabilir. Bununla beraber medenî haklarını kullanmak yetkisinden kısmen mahrum edilmiş reşit müssavirinin reyini alarak (M. K. 379) ; vasi de sulh mahkemesinden izin alarak (M. K. 405) sulh yapabilirler. Icra ve iflâs kanunumuz iflâs idaresinin müflis namına sulh akdedip edemiyeceği hakkında bir hükmü ihtiva etmemektedir. Fakat müflisin muallak dâvaları hakkında (İcra ve Iflâs 194) müstacel kararı̀r alabilen alacaklilar toplantısinin sulha karar verebileceklerine süpine yoktur (icra ve iflâs 224). Hükmî şahısların sulh akdetmek yetkilerine gelince: Köy kanunu muhtarın göreceği köy işleri içinde (madde 37) sulh aktedebileceğinden bahis etmiyor. 1580 sayll belediye kanunu, belediyelerin salâhiyetlerinden bahseden 19 uncu maddesinde (B No. 6) belediyenin tüzel kişi olarak sulha ehil olduğunu bildirir. 100 üncü maddesi $\mathbf{C}$ fıkrasında belediye idaresinin hükmî şahsiyetinin mümessili sıfa. tiyle belediye başkanına yetkili makamın ve heyetin tasdikine iktiran etmek sartiyle sulh akdetmek yetkisini verir. Belediye meclislerinin müzakere edeceği ve karar vereceği işleri tayin eden 70 inci maddesi de müddeabihi bin liradan fazla olan dâvaların sulhan tesviyesine karar vermeği meclise tevdi eyleyor, ve 71 inci maddesi bu kararın mahallî en bü. yük mülkiye memurunun tasvibiyle yürürlüğe gireceğini bildiriyor. Mahalli en büyük mülkiye memuru sulh kararını bir hafta içinde tasdik eimediği takdirde belediye meclisi kararın Danıştay tarafından tetkikini ister.

Umumî muvazeneye giren hükmi şahısların sulh yetkileri 4353 sayılı kanunun 30 ve 31 inci maddelerinde düzenlenmiştir. Dâvaya veya icraya intikal etmiş işlerde 10 bin liraya kadar (10 bin lira dahil) bir hakkıin tanınması veya menfaatın terkini tazammun eden anlaşmalar yapmağa. Maliye Bakanı yetkilidir. Bu miktarı geçen anlaşmalar Danıştayın uygun mütalâasiyle ve alınacak kararname ile yapılır.

Dâvaya ve icraya intikal etmemiş ihtilâfların sulh yolu ile çözülme. sinde menfaat görüldüğ̈ takdirde her Bakanlı 10 bin liraya kadar b̀ $\mathbf{y}$ hakkın tanınmasi veya menfaatın terkini tazammun eden anlaşmalar yapabilir. Bu miktarı geçen anlaşmalarda Danıstayın uygun mütalâusi alınmak şartiyle ancak Maliye Bakanlığınca alınacak kararname ile yapılabilir. Maliye Baş Hukuk Müşavirliğinin veya Danıştayın mütalâasına munalif olarak yapılacak sulhları akde yalnız Bakanlar Kurulu yetkilidir. 
2. - Sulhun mevzuu: a) Sulhun konusu ancak hususî hukuka ait ve tarafların üzerinde tasarufa kudretleri olan bir menfaattir. Başka bir tâbir ile mukavele mevzuu olabilen her sey ve tarafların mukavele ile tanzimine muktedir olduklar her husus sulh akdinin de konusu olabilir. $\mathrm{Bu}$ itibarla ahvali şahsiye sulh mevzuu olamaz.

Misal: A ve B birlikte kumar oynamaktalar iken birbirlerini oyunda hile ve desise yapmakla itham etmişler ve münazaaya tutuşmuşlardı'; fakat sonradan nizalarını bir sulh ile bitirmişlerdir. Yaptıkları sulh, eğer kazanmış olan tarafa kazandığının bir kısmını iadeye mecbur ediyor ise sahihtir. Fakat yaplan sulh gaybetmiș tarafı gaybına karşllk bir şey vermeğe taahhüt ettiriyorsa batıldır. (Borçlar K. madde 505). (Cosack U. Mitteis Bürger. Rechts).

Sulhun konusu olan medeni menfaat bir suçun neticesinden doğmuş ise yaplan sulh ceza takibatı üzerinde müessir olmaz.

Sulh bazı fiillerin yapılmamasına taallûk ediyorsa cezaî şart müeyyidesi altına da konabilir.

3. - Sulh bir mukavele olduğuna göre borçlar kanununun umumî hükümlerine tabidir.

a) Bu itibarla sulh esas. itibariyle bir sekle tâbi değildir. Kanunun bir șekle bağlı olmasını istemediği hususlarda sulh şekle bağlı değildir. Fakat konusu kanunun bir şekle bağll olmasını istediği hususlardan ise sulhun o sekilde yapılması zaruridir. Meselâ, sulh akdinde bir gayri men- kulün ferağı taahhüt edilmiş ise bu taahhüt resmi şekilde yapılmış olmalıdır. Sulh aktinde bir bağıslama vadinde bulunulmuş ise bu vaat yazilı şekilde olmalıdır. Demek ki sulhun bir șekle tâbi olup olmamasin! muhtevası tayin eyler. Yargitay dördüncü hukuk dairesinin 27-2-945 tarih esas 815 sayılı ve gayrimenkul alım satımında sulh un tabi olacağı şekile ait kararı: "Karşllklı taahhütleri havi akitlerde iki taraftan biri mütemerrit olduğu takdirde diğer tarafın zarar ve ziyan istemek hakkı vardır. Ancak bu kaide mutlak olmayıp, taahhüdün kanunen makbul ve muteber olmasiyle mukayyettir. Taahhütlerin muteber olmadığ haller de diğer tarafın zarar ziyan istemek hakkı yoktur.

Hadise, doktor Neșet Nacinin dâvacıda ilâmlı alacağı olan 6750 liranın istifasını sağlamak maksadiyle icraen haciz edilerek açı artırılmaya çıarılmıs olan gayrimenkule ait satış talebini ve icra takibini durđurmak ve ilâmlı alacağından vaz geçmekle beraber dâvacıya ayrıca 5000 lira vermek ve dâvacının dahi adı geçen gayrimenkulü Neșet Naciye ferağ etmek sartı ile sulh yapıldı̆ı iddia olunmustur. 
Borçlar kanununun açık hükü̈mlerine ve tapu mevzuatına Yargitay Genel Kurulunun içtihat birleştirme kararlarına göre gayrimenkule taallûk eden bütün muamelelerin tapu memuru huzurunda ve yalnız satış vadinin noter marifetiyle yapılması şart olduğundan gayrimenkulün alım ve satımında alım satım vadinin ve buna müteallik sulh akitlerinde bu şekle riayet olunmak lâzımdur. Aksi takdirde akit muteber olmaz. Taraflar arasında yapıldığı iddi olunan sulh akti şekle riayetsizlik sebebiyle hukukî bir hüküm ifade etmiyeceğinden dâvacının zarar ve ziyan istemeye hakkı yoktur. Bu sebeplere binaen itirazlarının reddiyle sözü geçen hükmün onanmasına"

b) Sulh karşllıkl taahhüdü ihtiva eden bir mukavele olmasına göre borçlar kanununun 81 ve 82 nci maddeleri hükümlerine tabi kalır.

Federal mahkeme 5, 11. 1915 tarihli kararında (taraflar Brunner Biel - Leuleringen havaî hat servisi J. d. T. 1916 sah. 450 ve 455). Taraflar Sulh akdini ne gibi bir ad ile adlandumrlarsa adlandursinlar mezkûr aktin borçlar kanununun umumî hükiumleri dahilinde itiraz edilebileceğini tebarüz ettirmektedir. Binaenaleyh tarafların kullandıkları tabirin ehemmiyeti olmadığını ve meselâ karşıllğında bir ivaz olmadan bedava bir tahsisat taahhüdünde bulunmak gibi hakikatte basit bir teberrudan ibaret olan bir sözümona sulhun taşıdığ isme göre tefsir edilmeyip mahiyetine göre tefsir edilmesi (mad: 18) lâzım geleceğini bildirmiştir. Binaenaleyh kanun veya nizamname (hadisede diğer tarafı teşkil eden anonim sirketin nizamnamesi) bedava bir tahsisat vermeğe mani olduğu takdirde bu teberrü batıl ve gayri meşru olur. (1) Brunner davasında Federal mahkeme hissedarlarından birinin isteği üzerine, yarg1cın umumî heyetin üçüncü bir şahsa sulh kılığına büründürerek bağladığı senelik tahsisatı iptal eylemesi lüzumuna hükmetmektedir.

Çỉnkü sirketi, mezkûr teberru'da bulunmağa mecbur eden hiçbir şey olmadığı gibi verilen tahsisat ta hissedarların nizamnameye göre alma. ğa haklaim olan hisselerini azaltacak mahiyettedir.

c) Her mukavele üzerinde tesiri olan hata, ihrak ve hilenin sulh mukavelesi üzerinde de tesiri vardır. Yalnız burada hata hakkında biraz iza. hat vermek lâzımdır. Sulhun saik ve sebebi olan hakda hata sulhun lü-

(1) Brunner davasun nakleden Emile Thilo mezkûr dava hükmünü şu misal ile șümullendiriyor: Tarafların miras hissesi üzerine sulh olup da bunlardan biri digerine verilen payın hakikatta bir kıymeti olmadığın kesin olarak bildirmesi halinde hüküm yine ayni olur. Bunu bilen tarafın diger tarafa teberruda bulunmak isteğini kabul ettirecek bir șey bulunmadığ takdirde iddia edilen sulha irade fesadı dolayısiyle itirazda bulunulabilinir. 
zumsuzluğuna sebep olamaz. Çünkü taraflarm sulha karar vermelerini icap ettiren ve sulh ile istihdaf eyledikleri gaye bunların veya hic olmazsa içlerinden birinin hata eylemekte olduğunu bizatihi iktiza ettirir; sulh olmak sebepleri arasinda haktan emin olmamak da vardır; bu sebepten sulha sevk eden hata sulhun lüzumsuzluğunu iddiaya mesnet olamaz. A ve B 40 liralık bir ödünç alacağından dolayı dâvaya tutuştuktan sonra A 20 lira mukabilinde dâvasindan sulh olduktan sonra B nin kendisine gerçekten 40 lira borcu olduğunu gösteren ve isbat eden senedi bulsa artık A sulhun hatadan dolayı lâzım olmadığını iddia edemez. Yal$\mathrm{nuz} B$, karşı tarafı sulha hile ve desise kullanarak sevketmiş ise işte $c$ zaman A yapılan sulh ile mülzem olmaz.

Bununla beraber hatanın sulh üzerinde hiç bir bozucu tesiri olmıyacağı iddia olunabilir mi? Bu soruya cevap verebilmek için tarafların şüpheli telâkki eyledikleri noktalar ile sabit telẩkki eyledikleri cihetleri birbirinden ayırmak lâzım gelir. Gerçektir ki her hukukî münasebet o hukukî münasebete vücut veren ve daha önce yapllmış olan fiilleri iktiza ettirir. Nizaın çlkabilmesi için bu mukaddem fiillerden bazısının sabit ve bazısının şüpheli olması lâzımdır. Şüpheli olan fiillerde, sabit telákki edilen ve hareket noktası olarak kabul edilmiş bulunan diğer filllere dayanır. Meselâ bir vasiyetname üzerinde yorumlar yapmak ve yapılan yorumlar münakaşa edilmek için hiç olmazsa bir vasiyetnamenin bulunduğunu ve bunun sahih olduğunu kabul eylemek lâzım gelir. Eğer vasiyetnamenin sıhhati tartışma konusu ise hiç olmazsa o vasiyetnamenin sahte olmadığı, meselâ ölünün eli ile yazılmış olduğunu kabul etmek iktizá eder. Binaenaleyh bütün mesele şu soruda temerküz etmiş ve o soruda ifadesini bulmus olur: Sulh mukavelesinin muhtevası mucibince sabit olarak telakki edilmiş olan fiillerde hatanın sulh mukavelesi üzerinde tesiri olacak mıdır? Yani tarafların varlıklarmı, yaptıkları sulh mukavelesine temel olarak aldıkları fiiller sulhun şartı olduğuna göre bu fiillerden birinde hatanın sabit olmasını infisahî bir şarta muadil olarak kabul etmek mi lâzım gelecektir? Bu soruya müsbet bir cevap veren Alman Medenî Kanunu bu gibi sabit telâkki edilmiş fiilleri sulhün muhtevası dışında kalmış olarak kabul etmiyor; onları sadece sulhün, sulh akti dışında bırakılmış saikı veya sebebi olarak telâkki etmiyor. Taraflarca sabit olarak kabul edilmiş fiilleri sulh akdinin muhtevasına dahil kıllyor. Binaenaleyh bu fiillerde hata, akdin muhtevasında hata telâkki edilerek hata eden tarafı sulh akdi ile, umumî hükümler dahilinde olarak mülzem kılmıyor. Imdi hatanın sulh akdi üzerinde müessir olduğunu tayin için sulhün muhtevasını iyice tahdit etmek ve bu muhtevaya göre 
tarafların hangi fiillerin subutlarını sulha temel ve karşılıklı fedakârlıklarının şartı mütekaddimi kılmış olduklarını araştırmak lâzımdır.

Isviçre içtihadı da bu merkezdedir. Bir tarafı Zala, diğer tarafi karı koca Joli - Zala bulunan dâva hakkında verdiği kararda Federal Mahkeme (J. d. T. 1922 sah. 290) tarafların yanlışlığı sonradan meydana çlkan bir fiili doğru olarak kabul eyledikleri ve yaptıkları sulhun esası kılmış bulundukları takdirde sulhün esash hata dolayısiyle iptali istenebileceğini teyit eylemiştir. Bu halin dışında ihtilâflı olarak telâkki edilmiş ve sulh ile bertaraf kılınmış hususlar tekrar bahis mevzuu kılinamaz.

Hata tabirini hatanın nazara aınlmasını icabettiren unsurlara tahsis etmek ve hataya yargıcı lâkayıt biraktıran unsurlara da şüphe, emniyetsizlik demek âdettir. Şüphe veya emniyetsizliğin subjektif veya objektif oiması hususuna gelince, bunun sadece subjektif olması kabul edilmiştir. Yani taraflar arasındaki huknkî münasebetin objektif şartlarına göre şüpheli olması lâzım gelmez. İmdi bir sulh akdini caiz kılan ve binaenaleyh sulh akdinin hata dolayısiyle lüzumsuz oldugunu ilân ettirmiyen şüphe taraflardan birinin şahsî hatasından da doğabilir. Şüphenin mahiyeti ne olur ise olsun bu şüpheye son verecek her mukavele hakikî bir sulh mukavelesi olur. Fakat şüpheyi yaratan hata yukarıda da arzedildiği üzere sulha temel olarak alınan mukaddem fiillere vukufsuzluktan doğuyorsa o zaman hataya düşmüs taraf sulh ile mülzem k1lınamaz. Şüphenin sulha vücut verebilmesi için onun mutlaka bir hataya dayanması da lâzım gelmez; davanın neticesini kestirememek de sulha sevkedecek bir emniyetsizliktir. Bu halde hakkın varlığında hataya düşülmüş olmadığı gibi şüphe de edilmemiștir. Yalnız hakkın gerçekleştirilebileceğinde emniyet hâsıl edilememiştir. En fena bir sulhun en iyi bir tarzda sevkedilecek davaya üstünlügüuni kabul ettiren saik da bu emniyetsizliktir. Hülâsa husumetin konusu hakkında hata yahut husumetin konusu hakkında emniyetsizlik sulh akdinin hata dolayısiyle lâzım olmıyacağını iddia ettiremez. Çünkü sulhün gayesi husumeti veya şüpheyi bertaraf kılmaktadır. Fakat sulhün muhtevasınca sabit olarak kabul edilmis ve sulha esas kılınmış olan vaziyet hakikate tekabül eylemediği ve vaziyetin malûm olduğu takdirde husumetin çımamış veya süuphenin hâsıl olmamış bulunacağı hallerde sulh lüzum ifade etmez. Binaenaleyh sulhün lüzum ifade eylememesi için:

a) Hatanın her iki tarafta mevcut olması lâzımdır.

b) Hata husumetin mevzuuna taallûk etmeyip vakıalara taallûk etmelidir. 
c) Hakiki vaziyetin bilinmesi halinde husumetin çımamış olacağı meczum bulunmalıdır. Meselâ vasiyetnamenin tefsirinden doğacak veya doğan husumeti sulh yolu ile bertaraf eyleyen mirasçlar sonradan vasiyetnamenin sahte olduğunu öğrenirler ise sulh lüzum ifade etmez. Hülâsa sahteliği meydana çıkan vesikalara dayanılarak yapılan sulh; yahut bertaraf edilmek istenen husumet zaten nihayete ermiş olup da taraftaların veya bir tarafın bunu bilmemiş olması halinde yaplan sulh; veya taraflardan birinin sulha esas kılinan şeyde hakkı olmadığı sonradan meydana çıkan vesikalarla sabit olduğu takdirde yapılmış olan uslh lüzum ifade etmez.

Federal mahkemenin tarafları Schvander ve Raeber dava (J. d. T. 1929. sah. 48). hakkında verdiği 8 Mayıs 1928 tarihli kararda sulhün cevherini göz önüne alarak diyorki: "Sulhün akdi zamanında ihtilâflı ve şüpheli bulunmuş olan noktaların hakiki mahiyetlerinin sonradan anlaşılmış ve tesbit edilmiş olması mezkûr noktaların ileride hataya dayandırılacak bir ihtilâfın mevzuu kılınmasına müsaade edilmez. Çünkü aksi takdirde tarafları sulha bilhassa sevketmiş mes'elelerin yeni baştan mevzuu kılınması mümkün kılınmış olur

Hatalı olarak taktir edilmiş bulunmasindan ötürü mukavelenin iptaline sebep olacak fiilin nazara alınabilmesi için mezkûr fiil ve şartın her iki tarafca şüphe götürmez bir hakikat olarak telâkki ve kbul edilmiş olması lâzımdır; hiç olmazsa taraflardan biri canibinden şüphe götürmez bir hakikat olarak telâkki ve kabul edilmiş diğer tarafın da buna vakıf bulunmuş olması lâzımdır. Binaenaleyh bir kazanın neticeleri, sulh ile tesbit edilirken, kazadan doğmuş zararın devamlı olmadığı kabul edilmiş bulunup da devaml zarar hakikatte mevcut idi ise bu hata mukavelenin esaslı bir unsuruna taallûk eylemesinden kabulüne ticarî hüsnüniyet müsaittir. Fakat bu esasl hatanın da ileri sürülebilmesi hatadan istifade edecek tarafın bu hali irade beyanının gerçekten esasını kılmış olmasına bağlıdır. Halbuki taraflar mukavelede, kazaya uğrıyanın kaza dolayısiyle dermeyan edebileceği ve dermeyan edilebilmesi muhtemel bütün iddialarda tatmin ve tazmin edilmiş bulunduğu açıç̧a söylenmiştir.

d. - Hile umumî hükümler dairesinde sulh mukavelesinin iptaline sebep olabilir. Hile, bir insanın doğru olarak ödevini yerine getirmemesinden ibarettir. Doğru olmak diğer tarafı dost doğru olarak haberdar etmektir. Dost doğru söylemek "Bir şey saklamaksızın, bir şey katmaksızın söylemektir" (Ceza Muh. U. K. 57). Herkesin, sözlerini hakikata uygun olarak söylemesi ahlâki bir vazifedir. Bu vazifeyi ihmal hileye vücut verir. Binaenaleyh "bir seyi saklamıs olmaktan (H. U. m. k. 339) dolayı suçlu olan kimse hile yapmış olur. Imdi hile hüsnüniyetin bildiril- 
mesini icap ettirdiği olaylar saklamaktır. Doğru söylemek ödevi her hadisede ayr bir sarta bağll kalır. Binaenaleyh kaide sulh akdine tatbik edildikte denilebilir ki; diğer tarafın, bildiği takdirde sulha muvafakatını vermiyeceği kesin olarak bilinen noktaların saklanması halinde sulh akdinin hile dolayısiyle iptali istenebilir (Federal mahkeme kararı 2. Mart 1922. J. d. T. 1922 sall. 290 tarafları Zala - Karı koca Joli - Zala). Federal mahkemesinin bu kararından hata bahsinde hataya taallûku nisbetinde bahsettik; hileye de ait bulunan mezkûr kararda deniyor ki : Bir ihtilâfa son vermek için aktedilmiş olan sulhun esaslı hata veya hile dolayısiyle iptali istenebilir. Taraflar sözleşme esnasında ileride yanlışlığ meydana çlkan bir fiili gerçekten var sanmışlar ise (hata) veya taraflardan biri diğerinin mezkûr fiil hakkında hata etmekte bulunduğunu bilmiş ise (hile) yapılmıs olan sulh akdine itirazetmek caiz olur; yani iptali istenebilir.

E. - İkrah. - Federal mahkeme yayınlanmamış olan bir ilâmında (7 Ekim 1931 - taraflam Darbre - Theynet) adalete cezar takibi mucip olacak bir şikâyetnamenin verilmesi tehdidi altında bırakılmağı; veya. açık bir iskândala maruz burakılmak tehdidini ikrah olarak kabul ediyor. $\mathrm{Bu}$ korku bir senelik zamanaşımından da fazla devam edebilir ve binaenaleyh zamanaşımının devamını; iskandalın patlamasına değin durdurabilir.

F. - Gabin. - Federal mahkeme ayni 7 Ekim 1931 tarihli ilâmında B kanununun 21 inci maddesinde kullanlan muzayıka tabirini yaln1z nağbunun (gabinden zarar görenin) para sıkıntısına maksur bir tabir olarak kabul etmiyor. Muzayaka hali, mağbunun bir çıkmaz içinde bunalması halinden başka bir şey değildir diyor. Bir çıkmaza girmiş mağbun, ancak karş tarafın ehven-i şer bulduğu tekliflerini kabul ile düştüğü çlkmazdan çıkabilmesi hali muzayıka halidir. Bu vaziyette mağbun kendisinden fahiş menfaatler istihsal edilmesine yani adeta soyulmasına müsaade etmek vaziyetinde kalıyor Yoksa. mağbun karşı tarafın, bir an sanılacağı gibi sadece hakkını kullanmasına katlanmış olmayor.

Binaenaleyh bir borç ikrarı meşru şekilde telkin edilmiş bir korkuya istinat etmekte ve bu yüzden bozuk bulunmakta olsa bile iptali, borç miktarının fahiş bulunmasına ve bu fahis halin karş1 tarafın müzayıka halinin istismar edilmiş bulunmasından doğmuş olmasına bağlı kalır. Çünkü aksi takdirde borç muteber bir sebebe istinat etmis olur. Muteber bir bir sebebe istinat eden borcun kabulü bir hakkın kullanılacağının verdiği korkuya da dayanması borcun sıhhatına halel vermez. Hakkın kullanulması tehdidinin ikrah sayılabilmesi için borcun miktarından çok fazla 
bir menfaatin istihsaline alet ve silâh kilınmış olması lâzımdır. Fazla istihsal edilen menfaatten sarfınazar edilirse borç borçlunun zimmetinde sabit olarak gözükür. Meselâ haksız bir fiilin sebep olduğu zarardan doğan borcun kabulü, muteber hukukî sebebi karşıladığı nisbette muteber kalır.

4) Sulhün lüzumsuzluğu yalnız sulh akdine tesir eder; icrasına tesir eylemez. Bu sebepten sulh akdi dolayısiyle yapılmış edalar ancak haksız mal iktisabına dayanılarak geri alınır.

5. - Sulhün hükmü yani hâsll ettiği neticeler:

Sulh, nizaı ve şüpheyi bertaraf eyler.

a) Eğer eski hukukî münasebet ifa edilecek ve yalnız sulh ile tadile ugratılacak ise rehin ve kefalet gibi fer'i haklar da baki kalır.

b) Sulh mevcut hukukî münasebeti tamamiyle değistirecek ise (tecdit), hususiyle bir sebep ve illeti olan hukukî münasebet yerine sebep ve illetinden mücerret bir borç mukavelesine çevrilecek ise rehin ve kefalet gibi mütefrri haklar da ortadan kalkar.

c) Sulh ancak zikrdilmiş konuya maksur kalır ve benzeri seylere veya murtebit şeylere teşmil edilemez. Binaenaleyh tarafların hukukî münasebetleri münhasıran sulhün muhtevası ile tayin edilir. Taraflar arasında eskiden mevcut olan ve sulh ile birlikte ortadan kaldırılmıs bulunan hukukî münasebet ancak sulhda bir boşluk bulunduğu takdirde veya taraflar sulh esnasında eski hukukî münasebetin nazara alınmakta devam edeceğini kararlaştırmıs oldukları takdirde nazara alını. Çünkü taraflar sulh ile hukukî münasebetlerini yeni baştan düzenlemeyi ve eski münasebeti ortadan kaldırmayı kastetmişlerdir.

Misal: A nın B den alacağı olan 1000 lira satış semenini taraflar sulh yolu ile 900 lira ödünce değiștirmişlerdir. B borçlu bulunduğu satış semenini sağlamak için $\mathrm{A}$ ya bir rehin vermişti. Yapılan sulhde $\mathrm{A}$ nın elinde bulunan rehinden bahis edilmemis ise, rehin A nın elinde kalmakta devam eyler. Yalnız mezkûr rehin artık ortadan kalkmış olan satış bedeli 1000 lirayı sağlamayı sulh ile yerine geçmis olan yeni 900 liralık ödüncü sağlar.

6. - Sulh nev'ileri ve sulh hakkındaki hükümler :

a) Mahkeme huzurunda yapılan sulh : Bu nevi sulhu mahkeme dişnda yapılan sulhtan ayıran hususiyet mahkeme huzurunda yapılan sulhun ilâm hükmünde olmasıdır (İcra ve tflâs K. Mad. 38).

Mahkeme huzurunda yapilan sulh tamamiyle taraflarin takdirine bırakılmıştır ve bu itibarla mahkeme tarafından tescilinden sonra gerek usul ve kanuna aykırı olmasindan veyahut nasfete uygun bulunmamasin- 
dan ötürü temyiz edilemez. Çünkü sulh ilâm hükmünde ise de ilâm değildir ve taraflar aralamndaki husumeti mutlaka hak ve nasfet dairesinde bertaraf etmeğe mecbur değillerdir.

Sulhun mahiyetinin mukavelevi olması onun tamamiyle kesinleșmis hükme benzetilmesine ve sulh yapılmış olduğu definin kesinleşmiş hüküm defi kuvvetinde tutulmasına imkân vermez. Binaenaleyh açılmış bir davaya karşı dâvalının, husumetin, mahkeme huzurunđa yapılmış bir sulh ile nihayete ermiş bulunduğu hususunda ileri sürmüş olduğu defin mahkemece reddedilmiş olması kanuna aykırı düssmez. Çünkü sulh iptal edilebilir (Federal mahkeme 25 - 9 - 1930 J. d. T. 1931 sah. 431).

Sulh müzakeresi esnasında geçen ikrar muteber değildir (Hukuk U. 236) : "Sulh müzakeresi esnasinda vukubulan ikrar dahi usulün 236 ncı maddesinin son fikrasinda gösterilen tam ikrar mahiyetinde bulunmadığ 1 ve gayri musaddak defterlerin dahi bunu teyid edici delillerden sayılmadığı halde mezkûr hususları nazara almaksızın yazılı olduğu üzre hüküm verilmesi yolsuzdur.,, (T. 31212-27/12/930).

Sarahaten mezuniyet verilmemiş ise avukat sulh olamaz (Hukuk U. 63) :

"Mahkeme huzurunda sulhü imza eden vekillerin sulh olmağa mezun bulunduğu vekâletname münderecatından anlaşlmakta olduğundan usul ve kanuna uygun hükmün onanmasina 22.3.1949 tarihinde oy birliği ile karar verildi." (1. Hukuk, esas 2126; karar 1380).

\section{HAKSIZ FIILDEN MUTEVELLIT ZARAR VE ZIYAN IDDIA-} SINDAN SULHA (BORÇLAR K. 45, 58) MISAL

Ankarada Dişkapıda ...... sokağında .... numaralı yeni yapılmakta olan binanın balkonundan beton bir parçanın kopması ve düşmesi yüzünden 17 Nisan 1949 da Hasan Hüseyin Dam vefat eylemiştir. ölü Hasan Hüseyin Damın karısı ve ölü İsmail kızı olan Fatma Dam kendi ve küçük çocukları :

a) Ahmet; 4 Mart 1945 doğumlu

b) Mehmet; 17 Haziran 1947 doğumlu

c) İsmail; 28 Şubat 1949 doğumlu.

namlarına (1) binanın sahibi Ankarada mukim Ali Yapar aleyhine zarar ve ziyan davası açmıştır. Fatma Dam kazanın beton ustası Nuri Dökerin verdiği ve Ali Yaparın malûmat ve muvafakatine istinat eden ha-

(1) Medeni kanun madde 264; işbu sulh için Fatma Dam'ın vesayet mahkemesinde izinalmaga ihtiyacı yoktur mad. 268. 
talı emirden neş'et eylemiş olduğunu da iddia eylemiştir. (2) Ali Yapar açlmıs davanın hukuken doğru olduğunu kabul etmemiş ve muarizada bulunmuștur.

Açılmış olan dava aşağıda Ali Yapar ile kendi ve küçük çocukları namına hareket eden (1) Fatma Dam arasında aşağıda yazılı şekilde yapllan sulh ile bertaraf edilmiştir Fatma Dam kendi namma ve velâyetinde bulunan küçük çocukları namına Ali Yaparla aşağıdaki hususları kararlaştırmıs ve kabul eylemiştir.

1. - Ali Yapar Fatma Dam'a 15 Nisan 1949 dan itibaren her sene 750 lira para verecektir. İşbu irat Fatma Dam'ın dul kaldığı yani tekrar evlenmediği müddetçe ödenecektir. Bununla beraber ölen Hasan Hüseyin Dam'ın 43 yaşında olması nazara alınarak işbu Ali Yapar tarafindan tediyesi kabul edilen senelik irat yirmi seneden fazla yani 15 Nisan 1969 dan fazla devam etmiyecektir(3).

Iradın tediyesi hakkında borçlar kanununun 509 uncu maddesi tatbik edilecek ve buna göre verilmesi lâzımgelen. miktar da bir hafta içinde ödenecektir.

2. - Fatma Dam evlâtlarının hepsi on sekiz yaşlarını bitirmeden evvel tekrar evlenecek veya ölecek oldukta Ali Yapar Fatma Dama tekrar evlenmesinden veya ölümünden evvel vermiş olduğu son irat devresinin nihayetinden itibaren isimleri yukarda yazll çocukların her birine 18 yaşlarını ikmale kadar senelik 150 lira irat verecektir.

3. - Irat müddeti içinde Fatma Dam'ın isimleri yukarda yazılı çocuklarından birinin ölümü takdirinde Ali Yapar vermesini taahhüt eylediği irattan 100 lira indirecektir. eyler.

4. - Fatma Dam kendi çocukları namına fazla iddiasından ferağat

5. - Fatma Dam hamile bulunduğu çocuk için de her türlü iddiadan feragat eyler. Fakat işbu sulh akdi ölü Hasan Hüseyin Dam'ın sağ olan babası İbrahim Dam'ın zarar ve ziyan iddia etmek hakkını ne takayyit ne de ihlâl eyler.

6. - Ali Yapar bu taahhüdünü evinin üzerinde tesis edeceği bir ipotek ile temin edecektir.

Ankara, 28 Mayıs 1949

Fatma Dam

Ali Yapar

(2) Kazanın esbabı mücbiredeń veya üçüncü bir şahsın yahut bizzat mağdurun hatasından doğmamış olduğunu gösterir (Borçlar Madde 58).

(3) Borçlar K. Madde 45 